\title{
Selection of fungi with biocontrol potential against the black spot disease of papaya ${ }^{1}$
}

\author{
Janieli Maganha Silva Vivas², Silvaldo Felipe da Silveira², \\ Pedro Henrique Dias dos Santos ${ }^{2}$, Danilo Batista Pinho ${ }^{3}$, Olinto Liparini Pereira ${ }^{4}$
}

\section{ABSTRACT}

The use of fungicides is the main control measure against the black-spot disease of papaya. The biological control is an alternative to that, being the selection of mycoparasitic fungi the first step in programs aiming at this kind of control. This study aimed to obtain and select fungi with potential to the biocontrol of the black spot disease of papaya. For this purpose, 24 isolates were collected from different regions and pathosystems, and then identified morphologically and by the ITS region sequencing. In order to evaluate the mycoparasite potential, two assessments, in a randomized block design, with three replications, were carried out in a shadehouse, being the obtained isolates inoculated on papaya leaves with black spot lesions. The average time for the appearance of mycoparasitism signs and the incidence of mycoparasitized black spot lesions were evaluated. Of the 24 isolates obtained, ten were from Hansfordia pulvinata, two from Lecanicillium lecaniium, two from Simplicillium lanossoniveum, one from Sarocladium implicatum and nine from Acremonium spp. A wide variability, concerning the mycoparasitism on black spot lesions, was observed, especially for the isolates H-611, H-613, H-614 and H-615, which showed the highest colonization averages. The results demonstrate that H. pulvinata has a great potential to be used as a biocontrol agent against Asperisporium caricae.

KEYWORDS: Carica papaya; Asperisporium caricae; Acremonium spp.; Hansfordia pulvinata.

\section{INTRODUCTION}

For the management of the black spot disease, caused by the fungus Asperisporium caricae (Speg.) Maubl., on papaya leaves in the field, one of the practices adopted to reduce the inoculum source is the elimination of the affected and senescent leaves (Suzuki et al. 2007). However, such a measure is not sufficient. Thus, conventional fungicide sprays

\section{RESUMO}

Seleção de fungos com potencial para biocontrole da pinta-preta do mamoeiro

A aplicação de fungicidas é a principal medida de controle da pinta-preta do mamoeiro. O controle biológico é uma alternativa, sendo a seleção de fungos micoparasitas a primeira etapa em programas com essa finalidade. Objetivou-se obter e selecionar fungos com potencial para o biocontrole da pinta-preta do mamoeiro. Coletaram-se, em diferentes regiões e patossistemas, 24 isolados, os quais foram identificados morfologicamente e pelo sequenciamento da região ITS. Para avaliar o potencial micoparasita, conduziram-se, em telado, dois ensaios, em blocos casualizados, com três repetições, sendo os isolados obtidos inoculados sobre folhas de mamoeiro com lesões de pinta-preta. Avaliaram-se o tempo médio para o aparecimento dos sinais de micoparasitismo e a incidência de lesões de pinta-preta micoparasitadas. Dos 24 isolados obtidos, dez eram de Hansfordia pulvinata, dois de Lecanicillium lecaniium, dois de Simplicillium lanossoniveum, um de Sarocladium implicatum e nove de Acremonium spp. Observouse ampla variabilidade dos isolados em micoparasitar a pinta-preta, com destaque para os isolados H-611, H-613, H-614 e H-615, por apresentarem as maiores médias de colonização. Os resultados permitem afirmar que $H$. pulvinata apresenta grande potencial para ser utilizado como agente de biocontrole de Asperisporium caricae.

PALAVRAS-CHAVE: Carica papaya; Asperisporium caricae; Acremonium spp.; Hansfordia pulvinata.

are necessary to control the disease (Barreto et al. 2011).

Despite being the main form of control, the intensive use of fungicides may select resistant isolates and negatively affect the human health, environment and fruit commercialization. Depending on the amount of fungicide found in the fruit, its commercialization may be unviable in the country, as well as its exportation, since the quality of the fruit

1. Manuscript received in Sep./2017 and accepted for publication in Nov./2017 (http://dx.doi.org/10.1590/1983-40632017v4749178). 2. Universidade Estadual do Norte Fluminense Darcy Ribeiro, Centro de Ciências e Tecnologias Agropecuárias, Laboratório de Entomologia e Fitopatologia, Campos dos Goytacazes, RJ, Brasil.E-mails: janielims19@yahoo.com.br, silvaldo@uenf.br, pedroh_dias@hotmail.com.

3. Universidade de Brasília, Departamento de Fitopatologia, Brasília, DF, Brasil.E-mail: danilopinho@unb.br.

4. Universidade Federal de Viçosa, Viçosa, MG, Brasil.E-mail: oliparini@ufv.br. 
must be attested through certification. Moreover, papaya has been described as a fungicide-sensitive crop (Vieira et al. 2003).

In view of the problems caused by fungicides in papaya crops, it is necessary to adopt alternative control strategies. Among them are the use of resistance-inducing products (Oliveira \& Nishijima 2014, Santos et al. 2017) and genetic resistance for the selection of resistant genotypes (Vivas et al. 2012 and 2015a, Poltronieri et al. 2017). In spite of the efforts employed in the development of control methods against the black spot disease of papaya, no product is known to induce resistance in the plant, and neither there are cultivars resistant to the disease.

An alternative strategy that may be adopted is the biological control. This type of control is considered a promising method to reduce the pesticide use and protect crops, thus adding value to the product going to the market, as it is based on procedures that reduce the pathogen population in a sustainable way and may be part of an integrated system for disease control. For papaya, the biological control is still little studied, with some reports on biocontrol agents such as bacteria and yeasts against several post-harvest fungi (BautistaBañosa et al. 2013, Lima et al. 2014). However, in the literature, there is no research on the black spot disease of papaya biocontrol. Thus, this is a pioneering study of great importance for the selection of isolates with mycoparasitic potential against $A$. caricae.

A fundamental step to implement a biological control program is the selection and isolation of antagonists. For this purpose, biocontrol agents can be selected by methods that are based on the evidence that the relevant organism somehow interferes with the pathogen development or reduces the disease. Considering the different forms of action of the antagonist on the pathogen, it is believed that a greater diversity of isolates leads to the use of more virulent antagonists, thus contributing to the identification of promising biological control agents.

Given the above, the present study aimed to obtain fungi with mycoparasitic potential, evaluate the fungal colonization by inoculation in the host and select the fungi that are agent precursors for the biological control of the black spot disease of papaya.

\section{MATERIAL AND METHODS}

Fungi with mycoparasitic potential were obtained from black spot lesions on papaya leaves collected in different locations, in 2012. The study also included mycoparasitic fungi obtained from leaves of okra [Abelmoschus esculentus (L.) Moench.] and scarlet eggplant (Solanum aethiopicum L. var. gilo Raddi) showing pathogens with signs of mycoparasitism similar to the black spot observed in papaya, as well as leaves of coffee (Coffea arabica L.) and frangipani (Plumeria rubra L.) showing rust mycoparasites (Table 1).

The mycoparasitic fungi obtained in pure cultures were submitted to monosporic isolation. In this procedure, spores diluted in a drop of sterile water were spread with a Drigalski spatula in a $2 \%$ agar-water medium under a glass slide, and then incubated in a humid chamber at $25^{\circ} \mathrm{C}$ and a 12 -hour photoperiod. Under light microscopy, the freshly germinated spores were transferred to a potatodextrose-agar (PDA) culture into Petri dishes. The pure cultures were maintained in tubes containing PDA culture medium tilted at $10{ }^{\circ} \mathrm{C}$ and also preserved using the Castellani's method (Gonçalves et al. 2016).

The morphological structure of the mycoparasites was observed by light microscopy and compared with the genus descriptions from a taxonomic manual of asexual forms of fungi (Seifert et al. 2011). In order to confirm the identification of the isolates, phylogenetic analyses were carried out. To do so, the mycelium of the isolates was macerated for extraction of genomic DNA with the protocol modified by Pinho et al. (2012), using the Wizard Genomic DNA Purification Kit (Promega). The eluted DNA was stored at $-20^{\circ} \mathrm{C}$ until use.

The quality of the genomic DNA extraction was analyzed by means of $1 \%$ agarose gel electrophoresis. Amolecular weight marker Kasvi 100 bp DNA Ladder was used to compare the fragment size. Amplification reactions were performed with the oligonucleotide primers ITS1 (5'-TCCGTAGGTGAACCTGCGG-3') and ITS4 (5'-TCCTCCGCTTATTGATATGC-3') (White et al. 1990). Reaction conditions were as it follows: $50 \mathrm{ng}$ DNA, 1x PCR buffer, 1.5 U Taq polymerase, $0.06 \mu \mathrm{M}$ primers $(3 \mathrm{pmol} /$ reaction), $0.2 \mathrm{mM}$ each dNTP, $1.5 \mathrm{mM} \mathrm{MgCl} 2$ and $50 \mu \mathrm{L}$ final volume. Amplification was performed in a Veriti $^{\circledR}$ Thermal Cycler with initial denaturation at $94{ }^{\circ} \mathrm{C}$ for 2 minutes; 35 cycles of 30 seconds at $94^{\circ} \mathrm{C}, 1$ minute at $55{ }^{\circ} \mathrm{C}$ and 1 minute at $72{ }^{\circ} \mathrm{C}$; followed by a final 
extension of 3 minutes at $72{ }^{\circ} \mathrm{C}$. PCR amplification products were visualized and compared in $1 \%(\mathrm{w} / \mathrm{v})$ agarose gel using a Kasvi 100 bp DNA Ladder. The samples were purified and sequenced by the Macrogen Inc., South Korea.

Nucleotide sequences were edited with the DNADragon software (Hepperle 2011). All sequences were corrected manually and the arrangement of the nucleotides at ambiguous positions was corrected using the primer sequences in the 5'-3' and 3' -5 ' orientations (Pinho et al. 2012). After verification, the sequences were compared in the GenBank database using the BLAST tool and aligned in the Muscle ${ }^{\circledR}$ program (Edgar 2004), by the MEGA v. 7 software (Kumar et al. 2016). Gaps (insertions/deletions) were treated as nonexistent. The phylogenetic tree was processed by Bayesian Inference (BI) analysis, using the Markov Chain Monte Carlo (MCMC) method with 10,000,000 generations sampled per 1,000 and $25 \%$ burn-in. The selected substitution model was GTR + I + G, according to the Akaike Information Criterion (AIC). The tree was root-dip inoculated with Verticillium dahliae DB 08052009-3.
In order to evaluate the isolate colonization in the black spot lesions, two experiments were carried out in a shadehouse covered with $50 \%$ shade cloth. The first experiment took place in July 2013 (with indoor temperature of $17-32{ }^{\circ} \mathrm{C}$ and relative humidity of $57-78 \%$ ) and the second one in November 2013 (indoor temperature of $20-30{ }^{\circ} \mathrm{C}$ and relative humidity of $64-98 \%$ ) (Figure 1). The experiments were designed in randomized blocks, with 25 treatments (24 mycoparasitic isolates and 1 control - water) and three replications. The experimental plot consisted of one plant per pot. The experiments used the 'Golden' papaya cultivar, considered susceptible to the black spot disease (Vivas et al. 2012).

The conidial suspension used in the experiment was prepared with isolates grown in a PDA culture medium for 13 days, at $25^{\circ} \mathrm{C}$ and a 12-hour photoperiod. After this period, the fungus was suspended in distilled water using a Drigalski spatula, and then the conidia were counted with a Neubauer chamber. The plants, grown in 5-L pots, 6 months old and with symptoms of the disease, had the lower part of their leaves sprayed with a $10^{5}$ conidia $\mathrm{mL}^{-1}$

Table 1. Isolates of mycoparasitic fungi obtained from different hosts and Brazilian locations.

\begin{tabular}{|c|c|c|c|c|}
\hline Code* & Host & Pathogen & $\begin{array}{l}\text { Collection site } \\
\text { (city - state) }\end{array}$ & $\begin{array}{c}\text { Collection } \\
\text { date }(\mathrm{d} / \mathrm{m} / \mathrm{y})\end{array}$ \\
\hline A-598 & Carica papaya $\mathrm{L}$. & Asperisporium caricae (Speg.) Maubl. & Alegre - ES & $04 / 06 / 2012$ \\
\hline A- 601 & C. papaya & A. caricae & Alegre - ES & $23 / 05 / 2012$ \\
\hline A- 602 & C. papaya & A. caricae & Mimoso do Sul - ES & $02 / 07 / 2012$ \\
\hline A-603 & C. papaya & A. caricae & Linhares - ES & $29 / 12 / 2012$ \\
\hline A-604 & C. papaya & A. caricae & Mimoso do Sul - ES & $18 / 11 / 2012$ \\
\hline A-616 & C. papaya & A. caricae & Alegre - ES & $27 / 06 / 2012$ \\
\hline A-617 & C. papaya & A. caricae & Cachoeiras de Macacu - RJ & $21 / 11 / 2012$ \\
\hline A-618 & C. papaya & A. caricae & Mimoso do Sul - ES & $29 / 06 / 2012$ \\
\hline A-619 & C. papaya & A. caricae & Mimoso do Sul - ES & $26 / 09 / 2012$ \\
\hline H-600 & C. papaya & A. caricae & Alegre - ES & $27 / 06 / 2012$ \\
\hline H-605 & C. papaya & A. caricae & Pesqueiro - SP & $29 / 12 / 2012$ \\
\hline H-608 & C. papaya & A. caricae & Mimoso do Sul - ES & $04 / 06 / 2012$ \\
\hline H-610 & Solanum aethiopicum L. var. gilo Raddi & Cladosporium sp. & Mimoso do Sul - ES & $12 / 06 / 2012$ \\
\hline H-611 & C. papaya & A. caricae & Colatina - ES & $26 / 09 / 2012$ \\
\hline H-612 & C. papaya & A. caricae & Alegre - ES & $29 / 06 / 2012$ \\
\hline H-613 & C. papaya & A. caricae & Campos dos Goytacazes - RJ & $23 / 05 / 2012$ \\
\hline H-614 & C. papaya & A. caricae & Mimoso do Sul - ES & $02 / 07 / 2012$ \\
\hline H-615 & C. papaya & A. caricae & Cachoeiras de Macacu - RJ & $18 / 11 / 2012$ \\
\hline H-623 & Abelmoschus esculentus (L.) Moench. & Pseudocercospora abelmoschi Ellis \& Everh. & Campos dos Goytacazes - RJ & $12 / 06 / 2012$ \\
\hline I-609 & C. papaya & A. caricae & Campos dos Goytacazes - RJ & $12 / 06 / 2012$ \\
\hline $\mathrm{I}-621$ & A. esculentus & P. abelmoschi & Campos dos Goytacazes - RJ & $12 / 06 / 2012$ \\
\hline L-620 & Coffea arabica $\mathrm{L}$. & Hemileia vastatrix Berk. \& Br. & Mimoso do Sul - ES & $30 / 06 / 2012$ \\
\hline L-622 & C. arabica & H. vastatrix & Alegre - ES & $03 / 07 / 2012$ \\
\hline S-599 & Plumeria rubra L. & Coleosporium plumeriae Pat. & Campos dos Goytacazes - RJ & $19 / 06 / 2012$ \\
\hline
\end{tabular}

$* \mathrm{~A}=$ Acremonium spp. $\mathrm{H}=$ Hansfordia pulvinata $; \mathrm{I}=$ Sarocladium implicatum $; \mathrm{L}=$ Lecanicillium lecanii $; \mathrm{S}=$ Simplicillium lanosoniveum. 
suspension of each of the mycoparasitic fungi included in the treatment. During the treatments, the plants were kept separated from each other, to avoid genetic drift of the mycoparasitic isolates.

The average time, in days, for the appearance of colonization signs (white mycoparasitic structures covering black spot lesions), the number of black spot lesions and the incidence (\%) of white mycoparasitized lesions at 15 days after inoculation were evaluated. For this evaluation, $10 \mathrm{~cm}$ of the midrib of the last viable leaf was considered, from tip towards petiole.

The data were submitted to analysis of variance. When a significant effect was observed, the Scott-Knott test $(\mathrm{p}<0.05)$ was conducted. In order to select the most promising isolates with ability to colonize black spot lesions, the isolates were included in a Biplot graph. All analyses were performed using the Genes software package (Cruz 2013).

\section{RESULTS AND DISCUSSION}

The phylogenetic analysis, performed with 37 taxa, resulted in the alignment of sequences of 516 characters, of which 229 were parsimony informative, 264 variable and 251 conserved. Confirming the morphological analyses, the 24 isolates were grouped into five clades (Table 1, Figure 2), which contain species previously described as having a biocontrol potential.

In the first clade, the following were isolated: H-600, H-605, H-608, H-610, H-611, H-612, H-613, H-614, H-615 and H-623, a highly synapomorphic monophyletic group of Hansfordia pulvinata (Berk. \& M. A. Curtis) S. Hughes (Figure 2). Of these, the isolate H-623 was obtained from Pseudocercospora abelmoschi (Ellis \& Everh.) Deighton in okra, H-610 from Cladosporium sp. in scarlet eggplant and the others from A. caricae in papaya (Table 1). The mycoparasitic potential of Hansfordia pulvinata (= Dicyma pulvinata) has been reported for other pathosystems. In Brazil, the most comprehensive study on $H$. pulvinata as mycoparasites analyzed leaf blight lesions in rubber trees caused by Pseudocercospora ulei (Henn.) Hora Junior \& Mizubuti (Junqueira \& Gasparotto 1991).

The isolates L-620 and L-622, derived from the causal agent of the coffee leaf rust, were identified

(a)



(b)

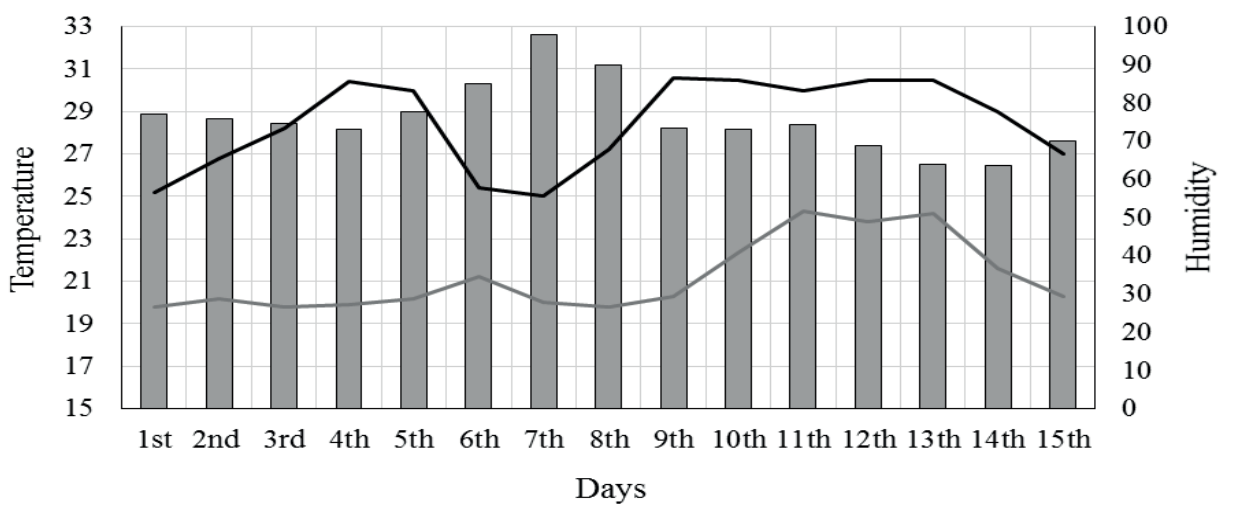

Figure 1. Temperature (line) and humidity (bar) measured during the experiments: the first took place in July 2013 (a) and the second one in November 2013 (b). 
as Lecanicillium lecanii (Zimm.) Zare \& W. Gams. The isolate S-599 from Simplicillium lanossoniveum (J. F. H. Beyma) Zare \& W. Gams was obtained from the causal agent of frangipani leaf rust. These genera belong to the same family (Cordyciptaceae) and are studied as entomopathogenic and mycoparasitic fungi in leaf rust (Jackson et al. 2012, Gauthier et al. 2014).

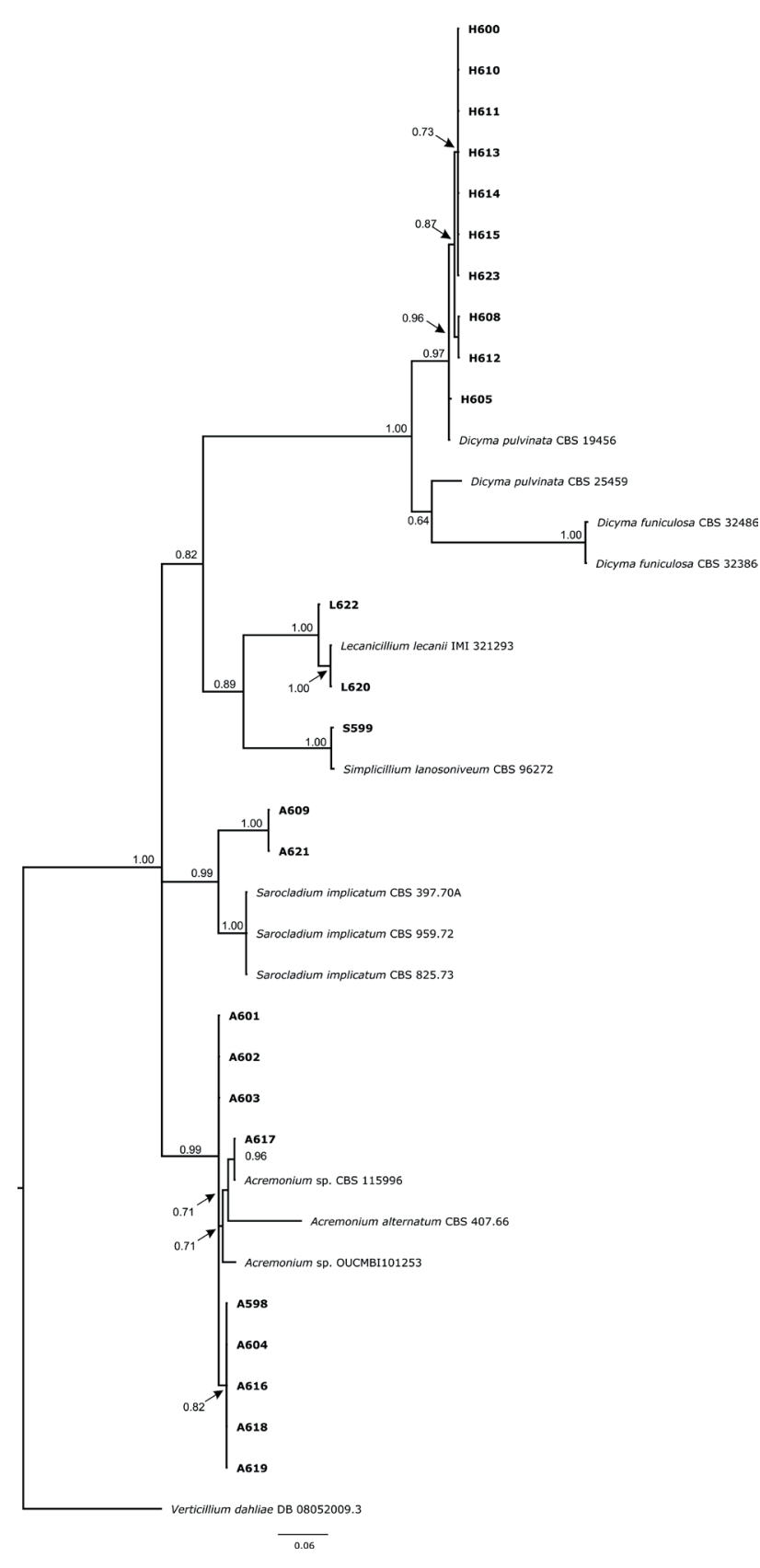

Figure 2. Bayesian inferences based on ITS-rDNA sequences. Subsequent probabilities are shown above the nodes. The isolates obtained in this study are highlighted in bold. The tree was root-dip inoculated with Verticillium dahliae DB 08052009-3.
The isolates I-609 and I-621 from Sarocladium implicatum (J. C. Gilman \& E. V. Abbott) Giraldo, Gené \& Guarro are mycoparasites isolated from A. caricae in papaya, and from P. abelmoschi in okra. The $S$. implicatum fungus, previously classified as Acremonium implicatum (J. C. Gilman \& E. V. Abbott) W. Gams (Giraldo et al. 2015), was described as mycoparasitic in leaf rust (Leinhos \& Buchenauer 1992).

For the first four species aforementioned, the phylogenetic analysis shows that the gene under study has enough phylogenetic signal to separate them into species (Figure 1). On the other hand, these molecular markers do not have enough phylogenetic signal for the different species of Acremonium spp., including the isolates A-598, A-601, A-602, A-603, A-604, A-616, A-617, A-618, A-619 and A-621, mycoparasites of $A$. caricae in papaya (Table 1 , Figure 2). The Acremonium genus may be potentially used in agriculture, acting as endophytic and mycoparasitic fungi (Wicklow et al. 2005, Choi et al. 2008). As previously mentioned, the obtained fungi have a biocontrol potential in other pathosystems. However, in papaya, this is the first time that the potential of such fungi in the biological control of Asperisporium caricae is investigated.

Regarding the number of days elapsed between the inoculation and appearance of mycoparasitism signs, it was not possible to perform the analysis of variance, as some isolates did not show any signs in the evaluated period (Figure 3). A variation between the isolates was observed in both experiments, concerning the appearance of mycoparasitism signs. In the first experiment, the signs appeared between 8 and 11 days after inoculation, while, in the second one, the signs appeared between 6 and 9 days after inoculation. The isolates of $H$. pulvinata stood out for taking a shorter time to mycoparasitize $A$. caricae (Figure 3).

Regarding the incidence of leaves with mycoparasitized black spot lesions, a significant variation $(p<0.01)$ was observed among the isolates. As for the number of black spot lesions on the leaves, no significant effect was noticed between the treatments and, consequently, all the isolates were inoculated in plants with a uniform number of lesions. It was also observed that, during the first experiment, the number of black spot lesions was lower than that observed in the second experiment. This could be explained by differences in the air temperature and 
humidity between the first and second evaluated periods (Figure 1). In addition, before the inoculation of the mycoparasites, the plants were under the same incubation conditions, under a shadehouse covered with $50 \%$ shade cloth (Sombrite ${ }^{\circledR}$ ). This way, environmental conditions affected both the manifestation of the disease symptoms and the efficiency of the inoculated mycoparasites.

In the second experiment, the environmental conditions were more favorable for both the pathogen (A. caricae) and the mycoparasites, since there were more lesions produced by the pathogen infested by the mycoparasites. Such conditions led to an increase in the incidence rate for all the mycoparasite isolates. In addition, the signs of mycoparasitism were observed earlier. With reference to the environmental conditions, temperatures of $20-30{ }^{\circ} \mathrm{C}$ and humidity of $64-98 \%$ were described in experiments as favoring both the pathogen and the mycoparasite (Suzuki et al. 2007, Vivas et al. 2005b). Considering the temperature variation in the two experiments,

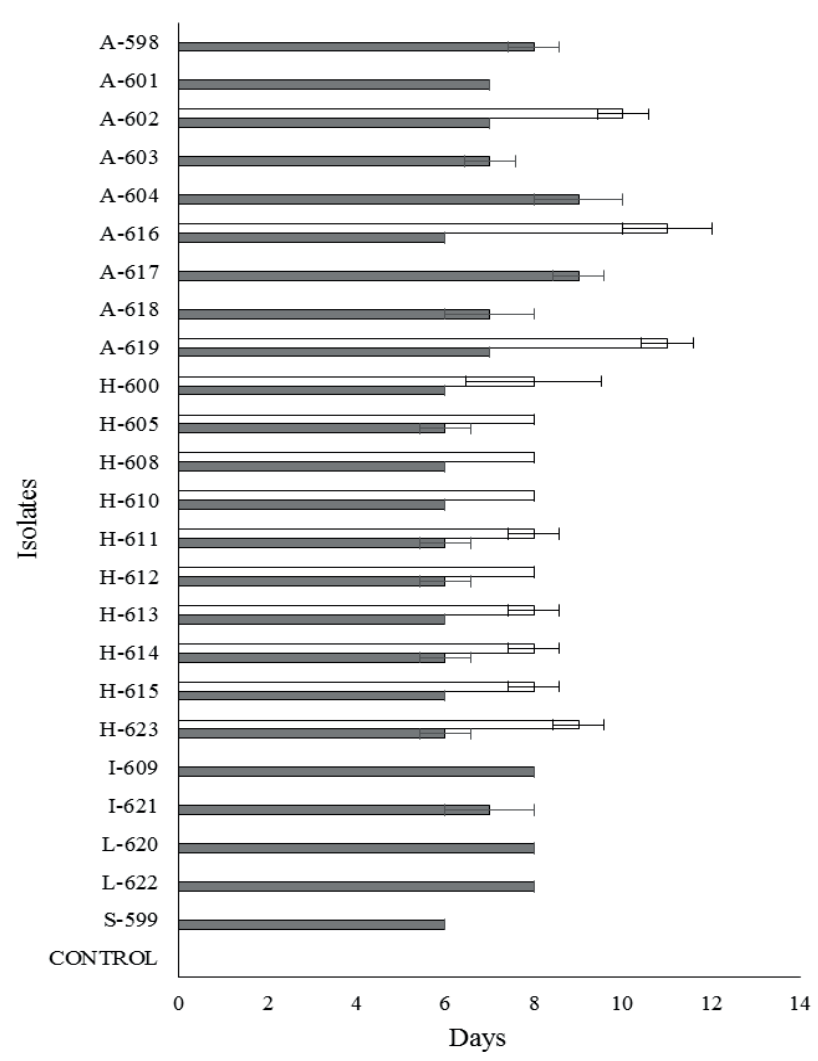

Figure 3. Average and standard deviation of the days after the inoculation of mycoparasites in papaya leaves with black spot symptoms, in a shadehouse, in two periods: July (white bars) and November (gray bars) of 2013. it is believed that the temperature had a smaller influence on the mycoparasitism, when compared to the humidity, since this was higher in the second experiment. However, further studies are needed to elucidate the effect of climatic factors on the occurrence of mycoparasitism on black spot lesions. The results obtained for the pathogen corroborate field observations by Suzuki et al. (2007), in the north of the Espírito Santo state, Brazil, who found that favorable conditions for the black spot disease in the field include temperatures of $25-30{ }^{\circ} \mathrm{C}$ and a high relative humidity of $80-100 \%$.

Regarding the incidence of mycoparasitic black spot lesions in the first experiment, the isolates A-619, A-616, A-602, H-610, H-623, H-600, H-614, H-612, H-613, H-608, H-611, H-605 and H-615 showed higher averages of mycoparasitized black spot lesions (Figure 4). In the second experiment, the isolates A-609, A-603, A-602, S-599, H-623, H-614, H-612, H-613, H-608, H-611, H-605 and H-615 showed the highest incidence averages for mycoparasitized lesions (Figure 4).

Thus, it is possible to identify potentially promising isolates for the biological control of the black spot disease of papaya, being H-611, H-613, H-614 and H-615 (H. pulvinata) the ones with higher mycoparasitic efficiency. These isolates were the ones that stood out in the two inoculation moments (Figure 4), reaching an incidence rate of $75.46 \%$ for the isolate H-611, in the second experiment.

Based on the results herein presented, the isolates L-620 and L-622 (L. lecanii), S-599 (S. lanosoniveum) and I-609 and I-621 (S. implicatum), although already related to the biological control in other studies, have not yet been reported as natural mycoparasites of Asperisporium caricae. Nevertheless, the present study shows that these fungi have the capacity to infect the pathogen, notably in favorable environmental conditions, as observed in the second experiment (Figures 3 and 4).

Isolates of Acremonium spp., although showing a greater potential than the isolates of L. lecanii, S. lanosoniveum and S. implicatum, did not stand out, when compared to isolates of $H$. pulvinata. A positive aspect concerning the use of Acremonium spp. lies in the fact that they produce chlamydospores. These give them a greater competitive and adaptive advantage to the environment, thus surviving longer under field conditions, for instance, fungi used as biological control agents such as Trichoderma spp., 


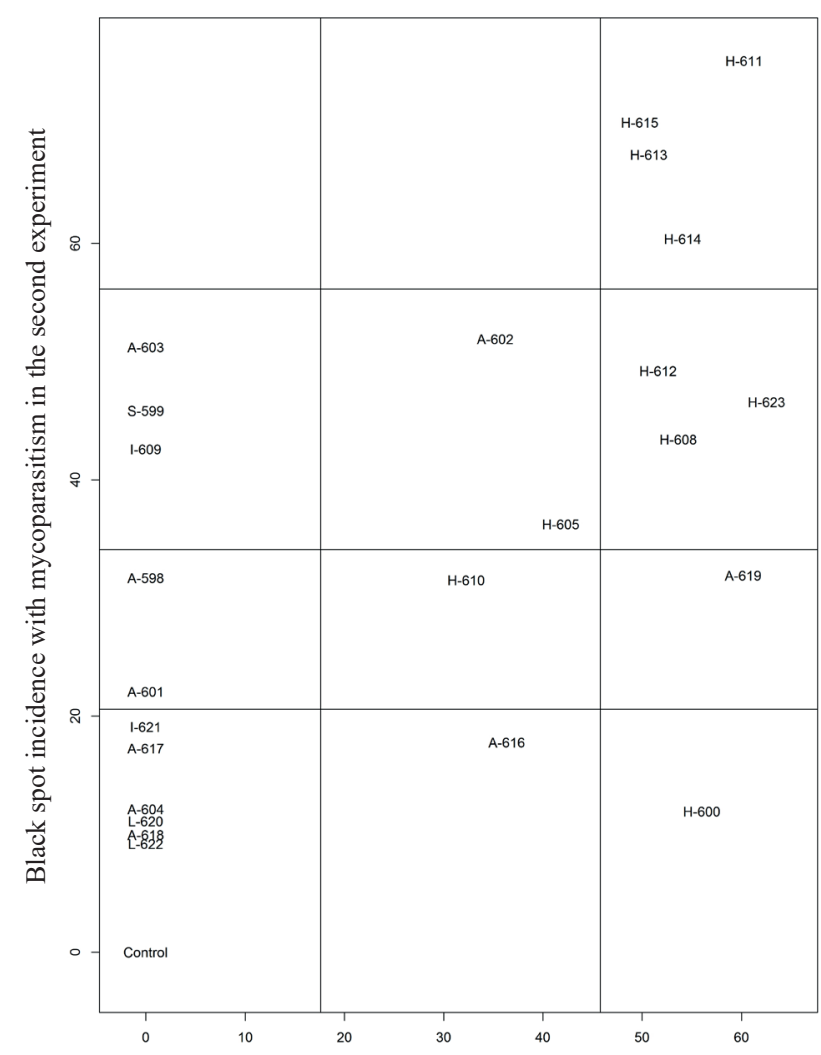

Black spot incidence with mycoparasitism in the first experiment

Figure 4. Incidence of black spot lesions with signs of mycoparasitism in two inoculation moments (first and second experiments), in a shadehouse. The internal lines define the division of the groups established by the Scott-Knott test $(\mathrm{p}<0.05)$.

Lewia chlamidospori formans B. S. Vieira \& R. W. and Pochonia chlamydosporia (Goddard) Zare \& Gams (Vieira \& Barreto 2010, Dallemole-Giaretta et al. 2012).

The obtained results confirm the mycoparasitic potential of the $A$. caricae phytopathogen for use in biological control programs against the black spot disease of papaya. In this study, isolates of the $H$. pulvinata species were the most promising ones, as they were the first to present signs of mycoparasitism, showing a higher efficiency in colonizing the black spot pustules under the different environmental conditions evaluated, especially the isolates H-611, H-613, H-614 and H-615. Further research should be conducted until a bioproduct is formulated and considered for commercial use. However, the first step was taken toward the selection of isolates potentially useable for biological control of the black spot disease of papaya.

\section{CONCLUSIONS}

1. The fungal species Acremonium spp., Hansfordia pulvinata, Sarocladium implicatum, Simplicillium lanosoniveum and Lecanicillium lecanii have the potential to colonize lesions produced by Asperisporium caricae;

2. The isolates H-611, H-613, H-614 and H-615 of Hansfordia pulvinata are the best mycoparasitic fungi for black spot lesions.

\section{REFERENCES}

BARRETO, L. F. et al. Avaliação de fungicidas no controle de Asperisporium caricae na cultura do mamoeiro. Revista Brasileira de Fruticultura, v. 33, n. esp., p. 399-403, 2011.

BAUTISTA-BAÑOSA, S. et al. A review of the management alternatives for controlling fungi on papaya fruit during the postharvest supply chain. Crop Protection, v. 49, n. 1, p. 8-20, 2013.

CHOI, G. et al. Mycoparasitism of Acremonium strictum BCP on Botrytis cinerea, the Gray. Journal of Microbiology and Biotechnology, v. 18, n. 1, p. 167-170, 2008.

CRUZ, C. D. Genes: a software package for analysis in experimental statistics and quantitative genetics. Acta Scientiarum Agronomy, v. 35, n. 3, p. 271-276, 2013.

DALLEMOLE-GIARETTA, R. et al. Screening of Pochonia chlamydosporia Brazilian isolates as biocontrol agents of Meloidogyne javanica. Crop Protection, v. 42, n. 1, p. 102-107, 2012.

EDGAR, R. C. Muscle: multiple sequence alignment with high accuracy and high throughput. Nucleic Acids Research, v. 32, n. 5, p. 1792-1797, 2004.

GAUTHIER, N. W. et al. Mycoparasitism of Phakopsora pachyrhizi, the soybean rust pathogen, by Simplicillium lanosoniveum. Biological Control, v. 76, n. 1, p. 87-94, 2014.

GIRALDO, A. et al. Phylogeny of Sarocladium (Hypocreales). Persoonia, v. 34, n. 1, p. 10-24, 2015.

GONÇALVES, R. C.; ALFENAS, A. C.; MAFIA, R. G. Armazenamento de micro-organismo em cultura com ênfase em fungos fitopatogênicos. In: ALFENAS, A. C.; MAFIA, R. G. Métodos em fitopatologia. Viçosa: Ed. UFV, 2016. p. 93-105.

HEPPERLE, D. DNA dragon 1.4.1 - DNA sequence contig assembler software. 2011. Available at: $<\mathrm{http}: / / \mathrm{www}$.dnadragon.com/>. Access on: 22 Jan., 2014.

JACKSON, D.; SKILLMAN, J.; VANDERMEER, J. Indirect biological control of the coffee leaf rust, Hemileia 
vastatrix, by the entomogenous fungus Lecanicillium lecanii in a complex coffee agroecosystem. Biological Control, v. 61, n. 1, p. 89-97, 2012.

JUNQUEIRA, N. T. V.; GASPAROTTO, L. Controle biológico de fungos estromáticos causadores de doenças foliares em seringueira. In: BETTIOL, W. (Org.). Controle biológico de doenças de plantas. Jaguariúna: EmbrapaCNPDA, 1991. p. 307-331.

KUMAR, S.; STECHER, G.; TAMURA, K. MEGA7: molecular evolutionary genetics analysis: version 7.0 for bigger datasets. Molecular Biology and Evolution, v. 33, n. 7, p. 1870-1874, 2016.

LEINHOS, G. M. E.; BUCHENAUER, H. Hyperparasitism of selected fungi on rust fungi of cereal. $Z$ Pflanzenkr Pflanzenschutz, v. 99, n. 1, p. 482-498, 1992.

LIMA, J. R. de et al. Efficiency of a yeast-based formulation for the biocontrol of postharvest anthracnose of papayas. Summa Phytopathologica, v. 40, n. 3, p. 203-211, 2014.

OLIVEIRA, A.; NISHIJIMA, W. Induction of resistance to papaya black spot elicited by acibenzolar-s-methyl. Plant Pathology Journal, v. 13, n. 2, p. 120-124, 2014.

PINHO, D. B. et al. An efficient protocol for DNA extraction from Meliolales and description of Meliola centellae sp. Nov. Mycotaxon, v. 122, n. 1, p. 333-345, 2012.

POLTRONIERI, T. P. S. et al. Selecting black-spot resistant papaya genotypes derived from backcrossing and hybrids. Genetics and Molecular Research, v. 16, n. 1, p. 1-11, 2017.

SANTOS, P. H. D. et al. Alternative control to black spot disease in papaya genotypes. Summa Phytopathologica, v. 43, n. 1, p. 60-62, 2017.

SEIFERT, K. et al. The genera of Hyphomycetes. Utrecht: CBS-KNAW Fungal Biodiversity Centre, 2011.
SUZUKI, M. S.; ZAMBOLIM, L.; LIBERATO, J. R. Progresso de doenças fúngicas e correlação com variáveis climáticas em mamoeiro. Summa Phytopathologica, v. 33, n. 2, p. 167-177, 2007.

VIEIRA, A.; RUGGIERO, C.; MARIN, S. L. D. Fitotoxicidade de fungicidas, acaricidas e inseticidas sobre o mamoeiro (Carica papaya L.) cultivar Sunrise Solo improved line 72/12. Revista Brasileira de Fruticultura, v. 25, n. 1, p. 175-178, 2003.

VIEIRA, B. S.; BARRETO, R. W. Liquid culture production of chlamydospores of Lewia chlamidospori formans (Ascomycota: Pleosporales), a mycoherbicide candidate for wild poinsettia. Australasian Plant Pathology, v. 39, n. 2, p. 154-160, 2010.

VIVAS, J. M. S.; VIVAS, M.; SILVEIRA, S. F. Efeito da temperatura sobre o crescimento e esporulação in vitro de fungos hiperparasitas de Asperisporium caricae. Pesquisa Agropecuária Tropical, v. 45, n. 1, p. 73-81, 2015 b.

VIVAS, M. et al. Patometria, parâmetros genéticos e reação de progênies de mamoeiro à pinta-preta. Bragantia, v. 71, n. 2, p. 235-238, 2012.

VIVAS, M. et al. Resistance to multiple foliar diseases in papaya genotypes in Brazil. Crop Protection, v. 71, n. 1, p. 138-143, 2015a.

WHITE, T. J. et al. Amplification and direct sequencing of fungal ribosomal RNA genes for phylogenetics. In: INNIS, M. A. et al. (Eds.). PCR protocols: a guide to methods and applications. San Diego: Academic Press, 1990. p. 315-322.

WICKLOW, D. T. et al. A protective endophyte of maize: Acremonium zeae antibiotics inhibitory to Aspergillus flavus and Fusarium verticillioides. Mycological Research, v. 109, n. 5, p. 610-618, 2005. 